\title{
EPIDEMIOLOGY OF ROTAVIRUS AND ASTROVIRUS INFECTIONS IN CHILDREN IN NORTHWESTERN NigeRIA
}

\author{
${ }^{1,2}$ M. Aminu, ${ }^{2}$ M. D. Esona, ${ }^{2}$ A. Geyer and ${ }^{2}$ A. D. Steele \\ ${ }^{1}$ Department of Microbiology, Faculty of Science, Ahmadu Bello University, Zaria-Nigeria \\ ${ }^{2}$ MRC/MEDUNSA Diarrhoeal Pathogens Research Unit, University of Limpopo, Medunsa Campus, Pretoria, \\ South Africa \\ Reprint request to: Dr. M. Aminu, Department of Microbiology, Faculty of Science, Ahmadu Bello University, \\ Zaria Nigeria. E-mail: maryamaminu@yahoo.com
}

\begin{abstract}
Background: Recent estimates attribute 527000 deaths in children less than five years of age to rotavirus diarrhea annually, with 145000 occurring in sub-Saharan Africa. Human astroviruses have been identified as one of the most frequent causes of infantile diarrhea, second in incidence only to rotavirus. This study was conducted to determine the prevalence of rotavirus and astrovirus and also to establish the circulating strains of rotavirus in a community in Nigeria where most diarrheic patients do not visit clinics or health care centers.

Methods: A total of 154 stool samples (134 diarrheic and 20 non-diarrheic) were collected from infants and young children less than 5 years of age from January-March 2002. Samples were obtained by house-to-house visit in randomly selected districts in Zaria, Northwestern Nigeria. The samples were screened for rotavirus and astrovirus antigens using commercially available Enzyme Linked Immunosorbent Assay (ELISA) kits. All positive group A rotavirus samples were further subjected to VP6 sub-group ELISA, Polyacrylamide gel electrophoresis (PAGE) to determine their RNA electropherotypes and Reverse transcription polymerase chain reaction (RT-PCR) to determine their VP7 and VP4 genotypes.

Results: Rotavirus and astrovirus antigens were detected in 9\% (12) and 5\% (7) of the 134 diarrheic stool samples respectively. No viral antigen was detected in the non-diarrheic stools. Rotavirus infection was more common in younger children than astrovirus infection. VP6 sub-group II specificity (58.3\%), long RNA electropherotypes (41.6\%), VP7 genotype G1 (33.3\%) and VP4 genotype P [6] (33.3\%) were the most common strains in circulation at that time in the community. Of significance is the fact that a large proportion of the rotavirus strains in circulation could not be assigned either a VP6 subgroup or RNA electrophoretic pattern probably as a result of low viral load.

Conclusion: In this community-based study, rotavirus and astrovirus were significantly associated with diarrhea. However, the prevalence of rotavirus infection among children appears to be low while that of astrovirus falls in the range seen in hospital-based studies around the continent.
\end{abstract}

Key words: Rotavirus, astrovirus, diarrhoea, children, community, Nigeria

\section{Résume}

Contexte: Des estimations récentes attribuent 527000 décès annuels d'enfants de moins de 5 ans à la diarrhée par rotavirus, parmi lesquels 145000 surviennent en Afrique Sub Saharienne. Les astrovirus humains ont été identifiés comme l'une des causes les plus fréquentes de diarrhée infantile, en second lieu viennent les atrovirus. Cette étude a été menée pour déterminer la prévalence des rotavirus et astrovirus et établir les souches circulantes de rotavirus dans une population du Nigéria ou la plupart des patients diarrhéiques ne consultent pas en clinique ni les centres de santé. 
Méthode: Un total de 154 échantillons de selles (134 diarrhéiques et 20 non-diarrhéiques) ont été collectés chez des enfants de moins de 5 ans de janvier à mars 2002. Les échantillons ont été recueillis par des visites de porte à porte dans des districts de Zaria (Nord-Ouest du Nigéria) sélectionnés par tirage au sort. Les échantillons ont été analysés à la recherche d'antigènes anti rotavirus et astrovirus en utilisant les kits ELISA disponibles dans le commerce. Tous les tests positifs pour identification du groupe A des rotavirus ont été soumis à l'identification par ELISA du sous groupe VP6 ainsi qu'à l'électrophorèse au gel de polyacrylamide pour déterminer leur type électrophorétique d'ARN. La PCRRT a été utilisée pour déterminer le génotype VP4 et VP7.

Résultats: Les antigènes anti rotavirus et astrovirus ont été retrouvés dans respectivement 9\% (12) et $5 \%(7)$ des 131 échantillons de selles de patients diarrhéiques. Aucun antigène viral n'a été détecté dans les selles non diarrhéiques. L'infection à Rotavirus étaient plus fréquente chez les jeunes enfants que celle à astrovirus. La spécificité du sous-groupe VP6, un long type électrophorétique d'ARN (41,6\%) le génotype G1 VP7 (33,3\%) et le génotype P [6] VP4 (33,3\%) ont été les brins circulants les plus communs a cette période dans la population. L'élément important est le fait que l'importante proportion de rotavirus circulants ne pouvaient être attribué à un sous groupe VP6 ou à un type électrophorétique en raison de la faible charge virale.

Conclusion: Dans cette étude, rotavirus et astrovirus étaient significativement associés à la diarrhée. II apparaît cependant que la prévalence de l'infection à rotavirus parmi les enfants semble faible tandis que celle des astrovirus tombe dans l'intervalle des études conduites dans les hôpitaux sur tout le continent.

Mots clés: Rotavirus, astrovirus, diarrhée, enfants, population, Nigeria

\section{Introduction}

Diarrheal diseases are a major source of morbidity and mortality among young children in developing countries. They have assumed a very special significance in the developing world, where they are responsible for $15 \%-30 \%$ of deaths in children less than 5 years of age. ${ }^{1}$ The immediate causes of gastroenteritis are often of an infectious nature and involve a variety of pathogenic microorganisms that include bacteria, parasites and viruses. ${ }^{2}$ Among these causative agents of diarrhea, viral diarrhea is associated with severe disease and hospitalization ${ }^{3}$ and is one of the major causes of mortality in children in sub-Saharan Africa. ${ }^{4}$ The viral agents that cause diarrhea in humans include rotaviruses, astroviruses, human caliciviruses and the enteric adenovirus. $^{5}$

Rotavirus has long been acknowledged to be a major etiological agent of gastroenteritis and responsible for a large proportion of morbidity and mortality associated with diarrheal illnesses. ${ }^{6}$ Recent estimates generated by Parashar and colleagues ${ }^{7}$ attribute 527000 deaths in children less than five years of age to rotavirus annually, with 145000 occurring in sub-Saharan Africa. ${ }^{4}$ This is likely to be under-estimation because only hospital-based studies have been considered. In Nigeria, a high incidence of childhood diarrhea is estimated to account for over 160000 of all deaths in children less than 5 years of age annually and of this number approximately $20 \%$ are associated with rotavirus infection. ${ }^{6}$

Rotaviruses consist of triple layered particle. The inner core surrounds the segmented genome of 11 genes, and is in turn enclosed by the major viral protein (VP) of the inner capsid. The outer capsid consists of the two major neutralizing antigens; a glycoprotein, termed the G-type (VP7) and a protease-sensitive protein, P-type (VP4). These antigens are responsible for conferring immunity and hence are a target for vaccine development. Although 15 different $G$ serotypes and $27 \quad \mathrm{P}$ genotypes $^{8-11}$ have been detected in humans, serotypes G1P[8], G2P[4], G3P[8], G4P[8] and G9P[8] are thought to be important causes of diarrhea in infants and young children worldwide. ${ }^{12}$

The human astroviruses have been identified as one of the most frequent causes of infantile gastroenteritis, second in incidence only to rotavirus. Astroviruses occur worldwide accounting for about $2 \%-16 \%$ of diarrhea in hospitalized children and $5 \%-$ $17 \%$ of diarrhea in the community. ${ }^{13}$ They are far more common than previously thought and their clinical significance continues to generate interest. ${ }^{14-}$ 16

Rotavirus infection is endemic in Nigeria and most studies conducted are hospital based. ${ }^{17-22}$ There are a few isolated reports on community studies ${ }^{23,24}$ on virus-associated gastroenteritis in children in Nigeria and only a couple of reports on the prevalence of astroviruses. ${ }^{15,25}$ The objective of this study was to determine the prevalence of rotaviruses and astroviruses and establish which strain of rotavirus circulates in Zaria, Nigeria, a community where most patients with diarrheal diseases do not visit clinics or health care centers. Such community studies would facilitate our understanding of the epidemiology of these viruses. 


\section{Materials and Methods}

\section{Location of study}

This study was conducted in randomly selected districts (Samaru, Jama'a, Zaria City, Sabon Gari and Bomo) in Zaria, Northwestern Nigeria. The area is semi-urban with people of different religious, educational and socio-economic backgrounds, living in neighborhoods with distinctly different levels of sanitation. Borehole and well water are the major source of drinking water supply in this area. Clinics and health care centers are tens of kilometers away and the majority of the houses have pit latrines. The main occupations here are cattle rearing and subsistence farming.

\section{Sample collection}

A total of 154 stool samples from children less than 5 years of age with diarrhea were collected by houseto-house visit in the selected districts from JanuaryMarch 2002. The samples included 20 non-diarrheic stools from matched healthy children which served as control. A diarrheic case in this study was defined as a child passing loose, liquid, watery or a bloody loose stool three or more times in a 24-hour period as reported by parents. The samples were stored frozen at $-20^{\circ} \mathrm{C}$ and transported to the MRC Diarhoeal Pathogens Research Unit (MRC DPRU), University of Limpopo Medunsa Campus, Pretoria, South Africa for analysis. Upon delivery, a $10 \%$ fecal suspension was prepared using balanced salt solution and the suspension stored at $4^{\circ} \mathrm{C}$. Basic demographic data, history of illness and clinical information concerning the children were obtained from caregivers using questionnaires.

\section{Viral detection}

Each $10 \%$ fecal suspension was screened for the presence of rotavirus and astrovirus antigens using commercially available enzyme immunoassay (EIA) kits (Rotavirus or Astrovirus IDEIA ${ }^{\mathrm{TM}}$ Dako, UK). All assays were performed according to the manufacturers' instructions.

\section{Polyacrylamide gel electrophoresis (PAGE)}

PAGE was performed by previously described procedure. $^{26}$ The dsRNA genome was extracted utilizing phenol-chloroform deproteinization and ethanol precipitation. The extracted RNA was applied to a $3 \%$ stacking / $10 \%$ resolving gel and eletrophorezed overnight at $100 \mathrm{~V}$ at room temperature using a discontinuous buffer system. The dsRNA band was visualized by silver staining according to the method described by Herring et al $^{27}$

\section{Subgroup specificity (VP6)}

All rotavirus-positive specimens were analyzed utilizing an 'in-house' VP6 ELISA as described by Steele and Alexander, ${ }^{28}$ Group-specific $^{29}$ and subgroup-specific monoclonal antibodies ${ }^{30}$ were a kind donation from H.B. Greenberg, Stanford University, USA.

\section{Rotavirus $G$ and $P$ typing PCR}

To determine the $G$ and $P$ types, RT-PCR assays were performed. Initially, 1062-bp (full-length) gene segment 9, encoding the VP7 glycoprotein of human group $A$ rotaviruses, was amplified using the forward primer Beg9 (5'-GGC TTT AAA AGA GAG AAT TTC CGT CTG G-3') and the reverse primer End9 (5'-GGT CAC ATC ATA CAA TTC TAA TCT AAG-3'). This was followed by semi nested PCR using the serotype-specific primers which identify the different $G$ types. ${ }^{31}$ To identify $P$ genotypes, a DNA fragment of $876 \mathrm{bp}$, was amplified from gene segment 4 (encoding VP4), using primers Con2 (5'-ATT TCG GAC CAT TTA TAA CC-3') in the forward direction and Con3 (5'-TGG CTT CGC CAT TTT ATA GAC A-3') in the reverse, followed by genotyping with P-typing primer. ${ }^{32}$ All PCR products were examined after electrophoresis in $1.2 \%$ agarose gels containing $4 \mu \mathrm{g}$ of ethidium bromide/ml. The characterization of the $\mathrm{G}$ and $\mathrm{P}$ genotypes amplicons was determined against a 100bp molecular size marker DNA ladder (Promega).

\section{Results}

A total of 154 stool samples, 75 from male and 79 from female young infants and children with diarrheoa, were screened for rotaviruses and astroviruses. Rotavirus and astrovirus antigens were respectively detected with a prevalence of $8.0 \%$ $(12 / 154)$ and $5 \%(7 / 154)$ in the total stool samples analyzed and with a prevalence of $9 \%(12 / 134)$ and $5 \%(7 / 134)$ in the diarrheic stools. No viral antigen was detected in the non-diarrheic stools. Children under 6 months old were more susceptible to rotavirus infection that occurred with the highest incidence in children 4-6 months old while astrovirus infection was more frequently detected among children older than 6 months (Table 1). Rotavirus and astrovirus were detected at almost the same frequency in both sexes $(P>.05)$.

\section{PAGE}

Of the 12 rotavirus positive stool samples analyzed by PAGE, 7 (58\%) yielded typical rotavirus electrophoretic profiles while the remaining 5 showed no profiles. Of the 7 isolated strains, 5 were long electropherotypes while 2 were short electropherotypes. In total, 4 distinct electrophoretic variants were noted (L1, L2, L3 and S1) in this community-based study (Figure) 1 . The long electrophoretic profiles, L1 and L2 were the most prevalent rotaviruses in circulation during the study. 


\section{VP6 sub-group ELISA}

Seven out of the 12 rotavirus positive strains that were subjected to subgroup (SG) ELISA were of SGII specificity while 3 strains could not be assigned any specific subgroup (Table 2). Four of the strains with long electropherotypes exhibited SGII specificity while 1 out of the 2 strains with short electrophoretic profiles was found to have SGI specificity.

\section{VP7 and VP4 genotyping}

A total of 12 EIA positive samples were subsequently genotyped. After RT-PCR, first round PCR products for both VP7 and VP4 could be obtained from 9 strains. Three strains could not be amplified. A total of 6 strains could be assigned a $G$ genotype. Two $G$ types, namely $\mathrm{G} 1$ and $\mathrm{G} 2$ were observed during the study. The predominant $\mathrm{G}$ type observed was G1 (4 strains) with two G2. For VP4 genotyping, a total of 4 strains were $P$ genotyped while 5 could not be assigned any $P$ type.
Assessment of clinical symptoms associated with rotavirus and astrovirus infections showed that astrovirus infection occurred more commonly in older children generally with fever while rotavirus infection was more common in the younger age group with vomiting as an additional symptom. In addition, children with rotavirus-associated diarrhea were more dehydrated and had been given more ORS than those with astrovirus-associated diarrhea. Majority of the children belong to low socioeconomic class with no access to modern toilet facilities and tap water. Almost all (92\%) of the household neither boil nor treat the well or borehole water they drink. The majority of the children had received medication obtained from the numerous nearby medicine stores. The medication included antibiotics such as, thalazole, metronidazole, ampicillin, tetracycline and the anti-malarial, chloroquine commonly sold directly from the shelf.

Table 1. Age and Sex of Rotavirus and Astrovirus infected children

\begin{tabular}{|c|c|c|c|c|c|c|c|c|}
\hline & Rotavirus & & & & Astrovirus & & & \\
\hline & Male & Female & Total & $\begin{array}{l}\text { \% } \\
\text { positive }\end{array}$ & Male & Female & Total & $\begin{array}{l}\% \\
\text { positive }\end{array}$ \\
\hline $0-3$ & $1 / 8$ & $1 / 7$ & $2 / 15$ & 13.3 & $0 / 8$ & $0 / 7$ & $0 / 15$ & 0 \\
\hline 4-6 & $3 / 16$ & $3 / 14$ & $6 / 30$ & 20.0 & $0 / 16$ & $0 / 14$ & $0 / 30$ & 0 \\
\hline $7-9$ & $0 / 6$ & $0 / 15$ & $0 / 21$ & 0 & $0 / 6$ & $1 / 15$ & $1 / 21$ & 4.8 \\
\hline $10-12$ & $1 / 13$ & $0 / 5$ & $1 / 18$ & 5.6 & $1 / 13$ & $1 / 5$ & $2 / 18$ & 11.1 \\
\hline $13-45$ & $0 / 32$ & $3 / 38$ & $3 / 70$ & 4.3 & $4 / 32$ & $0 / 38$ & $4 / 70$ & 5.71 \\
\hline Total & $5 / 75$ & $7 / 79$ & $12 / 154$ & 8.0 & $5 / 75$ & $2 / 79$ & $7 / 154$ & 5.0 \\
\hline
\end{tabular}

Table 2. Electropherotypes and subgroups identified in Zaria, Nigeria

\begin{tabular}{llllll}
\hline Electropherotype & Subgroup & & & & Total \\
\hline \multirow{2}{*}{ Long } & $\mathbf{I}$ & II & I+ II & Neither I nor II & \\
\cline { 2 - 6 } Short & - & 4 & - & 1 & 5 \\
No pattern & 1 & - & 1 & - & 2 \\
Total & - & 3 & - & 2 & 5 \\
\hline
\end{tabular}

Figure 1. RNA electrophoretic patterns of Rotavirus strains obtained

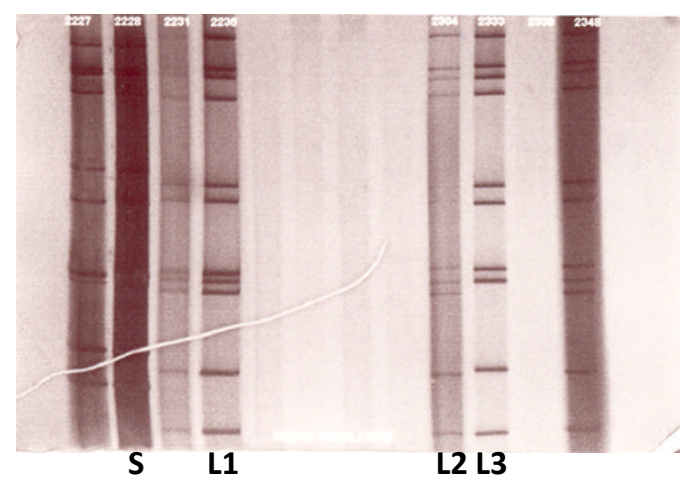




\section{Discussion}

In this community-based study, rotaviruses and astroviruses were detected from stool samples obtained from young children with diarrhea. Human rotavirus strains from these stools were antigenically sub-grouped by VP6 specific monoclonal antibodies and the strains were further analyzed as to their genomic profile determined by PAGE and RT-PCR.

Rotavirus and astrovirus were detected in $9 \%$ and $5 \%$ of the diarrheic stools respectively and none in the control stools. This implies that these viruses are significantly associated with diarrhea. Rotavirus has been shown to be the most important cause of viral diarrhea in children less than 5 years of age in Nigeria, ${ }^{22,33}$ as also observed in Ghana ${ }^{34}$ and Cameroon. ${ }^{35}$ The prevalence of rotavirus infection in this community-based study was lower than previously reported in hospital-based studies in Nigeria, ${ }^{22,33}$ Ghana $^{34}$ and Cameroon. ${ }^{35}$ On the other hand, the detection rate of astrovirus in this study was similar to that reported by Pennap and colleagues, $^{15}$ even though their study was hospital based. This result shows that many infections due to astroviruses in this area may not be detected since most studies are hospital based. In addition, many diarrhea cases are treated at home and not reported in clinics; implying that the prevalence of astrovirus infection and perhaps rotavirus infection previously reported in this area does not reflect the true picture of these infections. This highlights the need for more community-based studies in this area.

Significantly, astrovirus was detected mainly among children $>6$ months old while rotavirus infection predominated in those $<6$ months old. This implies the burden of rotavirus disease is highest in the youngest and most vulnerable in this area unlike developed countries where rotavirus infections are more common in children 9-15 months old. ${ }^{6}$

As expected, rotavirus strains with VP6 SGII and long RNA electropherotypes were the most predominant in this study. This result is similar to what has been reported globally. ${ }^{34-36}$ Although cocirculation of different electropherotypes in a community is common, there was no genomic variant in this community. This may suggest that the gene pool is relatively stable and antigenic drift and gene reassortment among circulating strains is negligible. In addition, this could relate to the small number of positive samples that were analyzed.

The RT-PCR technique is the most widely used method for the detection of rotavirus nucleic acid. This is due to its extreme sensitivity and specificity in detecting rotavirus dsRNA in stool samples. In this study, rotavirus with VP7 serotype G1 was the most predominant strain found in circulation, followed by rotavirus $\mathrm{G} 2$. The detection of $\mathrm{G} 1$ serotypes as the most common strain is not surprising as it is the most abundant rotavirus strain globally. ${ }^{8,35,37,38}$ Rotavirus with VP4 P[6] genotype was the only genotype detected in this study. The $P[6]$ genotype was previously thought to be associated with neonatal rotavirus strains and hence thought to be associated with asymptomatic infection. ${ }^{39}$ However in this study it was associated with symptomatic diarrhea as has been shown in studies conducted in Cameroon, ${ }^{35}$ Nigeria ${ }^{22,40}$ and Ghana. ${ }^{41}$ This implies the genotype is increasingly being associated with symptomatic diarrhea

In conclusion, rotavirus and astrovirus were significantly associated with diarrhea in this community-based study in Zaria, Nigeria. Rotavirus infection however, occurred at a low level. This study also identified children with a milder rotavirus infection. The strains that could not be genotyped may represent other unrecognized genotypes, which need further investigation. These results add to the existing data on rotaviruses and astroviruses infection in Nigeria and may be important for vaccine development and successful implementation of a future rotavirus immunization program. Although the figures in this study are small, they indicate trends that may be significant with respect to virus infection, seasonality and temporal relationship with respect to infection.

\section{References}

1. Kosek M, Bern C, Guerrant RL. The global burden of diarrhoeal disease as estimated from studies published between 1992 and 2000. Bull World Health Org. 2003;81:197-204.

2. Estes MK. Introduction. In: Chadwick D, Goode J.A. (Eds). Gastroenteritis Viruses. Novartis Found Symp. 2001; 238: 1-4.

3. Goodgame RW. Viral causes of diarrhoea. Gastroenterol Clin North Am. 2001;30:779-795.

4. Molbak K, Fischer-Perch TK, Mikkelsen CS. The estimation of mortality due to rotavirus infections in sub-Saharan Africa. Vaccine. 2000;19:393-395.

5. Proceedings of the Symposium on Gastroenteritis Viruses. London, United Kingdom, 16-18 May 2000. Novartis Found Symp. 2001;238:1-2.

6. Parashar UD, Hummeiman EG, Bresse JS, Miller MA, Glass RI. Global illness and deaths caused by rotavirus disease in children. Emerg Infect Dis. 2003;9:565-572.

7. Parashar UD, Gibson CJ, Bresse JS, Glass RI. Rotavirus and severe childhood diarrhea. Emerg Infect Dis. 2006;12:304-306.

8. Hoshino Y, Kapikian AZ. Rotavirus serotypes: classification and importance in epidemiology, immunity and vaccine development. J Heatlh Popul Nutr. 2000;18:5-14.

9. Khamrin P, Maneekarn N, Peerakome S, et al. 
Novel porcine rotavirus of genotype $P$ [27] shares new phylogenetic lineage with $G 2$ porcine rotavirus strain. Virology. 2007;361:243-252.

10. Martella V, Ciarlet $M$, Banyai $K$, et al. Identification of a novel VP4 genotype carried by a serotype $\mathrm{G} 5$ porcine rotavirus strain. Virology. 2006;346:301-311.

11. Rahman M, Matthijnssens J, Nahar S, et al. Characterization of a novel P[25],G11 human group a rotavirus. J Clin Microbiol. 2005;43:32083212.

12. Gentsch JR, Woods PA, Ramachandran M, et al. Review of $G$ and $P$ typing results from a global collection of rotavirus strains: implications for vaccine development. J Infect Dis. 1996;174(Suppl 1):S30-S36.

13. Herrmann JE, Taylor DN, Echeverria P, Blacklow NR. Astroviruses as a cause of gastroenteritis in children. N Engl J Med. 1991;324:1757-1760.

14. Taylor MB. Human astroviruses in Africa: Is there a problem? Proceedings of the third African Rotavirus Symposium Held at the Noguchi Memorial Institute for Medical Research, Legon, Ghana. 2002: 15-17 September.

15. Pennap G, Pager CT, Peenze I, et al. Epidemiology of astroviruses infection in Zaria, Nigeria. J Trop Pediatr. 2002;48:98-101.

16. Oh D, Schreier E. Molecular characterization of human astroviruses in Germany. Arch Virol. 2001;146:443-455.

17. Oyejide $\mathrm{CO}$, Fagbami AH. An epidemiological study of rotavirus diarrhoea in a cohort of Nigerian infants: incidence of diarrhoea in the first two years of life. Int J Epidemiol. 1988;17:908-912.

18. Omotade OO, Olaleye OD, Oyejide CO, Avery RM, Pawley A, Shelton AP. Rotavirus serotypes and subgroups in gastroenteritis. Niger J Paediatr. 1995;22:11-17.

19. Paul MO, Paul BD. Rotavirus infection among children in hospital in Nigeria. J Infect. 1986;12:39-47.

20. Gomwalk NE, Gosham LT, Umoh JU. Rotavirus gastroenteritis in paediatric diarrhoea in Jos, Nigeria. J Trop Pediatr. 1990;36:52-55.

21. Olusanya $\mathrm{O}$, Taiwo $\mathrm{O}$. Rotavirus as an aetiological agent of acute children diarrhoea in Ile-Ife, Nigeria. East Afr Med J. 1989;66:100-104.

22. Aminu M, Ahmad AA, Umoh JU, Dewar J, Esona $M D$, Steele AD. The epidemiology of rotaviruses in Northwestern Nigeria. J Trop Pediatr. March 2008 (doi: 1093/tropej/fmno21).

23. Fagbami $\mathrm{AH}$, Oyejide $\mathrm{CO}$, Enahoro F. Neonatal rotavirus infection in urban and rural communities in Nigeria. Trop Geogr Med. 1987;39:341-4..

24. Ojeh CK, Atti DJ, Omotade OO. Comparison of the genome dsRNA of human rotavirus strains in parts of Ibadan, Nigeria. Afr J Med Med Sci. 1995;24:359-63.

25. Audu R, Omilabu SA, Peenze I, Steele D. Viral diarrhoea in young children in two districts in Nigeria. Cent Afr J Med. 2002;48:59-63.

26. Steele AD, Alexander JJ. Molecular epidemiology of rotaviruses in black infants in South Africa. J Clin Microbiol. 1987;25:2384-7.

27. Herring AJ, Inglis NF, Ojeh CK, Snodgrass DR, Menzies JD. Rapid diagnosis of rotavirus infection by direct detection of viral nucleic acid in silver-stained polyacrylamide gels. J Clin Microbiol. 1982;16:473-477.

28. Steele $A D$, Alexander JJ. The relative frequency of subgroup I and II rotaviruses in South Africa. J Med Virol. 1988;24:321-327.

29. Beards GM, Campbell AD, Cottrell R, et al. Enzyme-linked immunosorbent assay based on polyclonal and monoclonal antibodies for rotavirus detection. J Clin Microbiol. 1984;19:248-254.

30. Greenberg H, McAuliffe V, Valdesuso J, et al. Serological analysis of the subgroup protein of rotavirus using monoclonal antibodies. Infect Immun. 1983;39:91-99.

31. Gouvea V, Glass RI, Woods P, et al. Polymerase chain reaction amplification and typing of rotavirus nucleic acid from stool samples. J Clin Microbiol. 1990;28:276-282.

32. Gentsch JR, Glass RI, Woods $P$, et al. Identification of group A rotavirus gene 4 types by polymerase chain reaction. J Clin Microbiol. 1992;30:1365-1375.

33. Avery RM, Shelton AP, Beards GM, Omotade OO, Oyejide OC, Olaleye DO. Viral agents associated with infantile gastroenteritis in Nigeria: Relative prevalence of adenovirus serotypes 40 and 41, astrovirus and rotavirus serotypes 1 to 4 . J Diarrhoeal Dis Res. 1992;10:105-108.

34. Armah GE, Steele AD, Binka FN, et al. Changing patterns of rotavirus genotypes in Ghana: emergence of human rotavirus G9 as a major cause of diarrhea in children. J Clin Microbiol. 2003;41:2317-2322.

35. Esona MD, Armah GE, Steele AD. Molecular Epidemiology of rotavirus infection in western Cameroon. J Trop Pediatr. 2003;49:160-163.

36. Steele AD. Association of subgroup antigenicity and RNA electrophoretic profile of rotaviruses isolated in white children with gastroenteritis. S Afr J Sci. 1989;85:370-372.

37. Audu R, Omilabu SA, de Beer MC, Peenze I, Steele AD. Diversity of human rotavirus VP6, VP7 and VP4 in Lagos State, Nigeria. J Health Popul Nutr. 2002;20:59-64.

38. Adah MI, Wade A, Taniguchi K. Molecular epidemiology of rotaviruses in Nigeria: detection of unusual strains with G2P[6] and G8P[1] 
specificities. J Clin Microbiol. 2001;39:39693975.

39. Steele AD, Van Niekerk MC, Geyer A, Bos P, Alexander JJ. Further characterization of human rotaviruses isolated from asymptomatically infected neonates in South Africa. J Med Virol. 1992;38:22-26.
40. Adah MI, Rohwedder A, Olaleye OD, Durojaiye $\mathrm{OA}$, Werchau $\mathrm{H}$. Further characterization of field strains of rotavirus from Nigeria VP4 genotype P6 most frequently identified among symptomatically infected children. J Trop Pediatr. 1997;43:267-274.

41. Armah GE, Pager CT, Asmah RH, et al. Prevalence of unusual human rotavirus strains in Ghanaian children. J Med Virol. 2001;63:67-71. 